International Research Journal of Management, IT \& Social Sciences
Available online at https://sloap.org/journals/index.php/irjmis/
Vol. 9 No. 1, January 2022, pages: 119-130
ISSN: 2395-7492
https://doi.org/10.21744/irjmis.v9n1.2014

\title{
The Influences of Job Satisfaction and Organizational Commitment on Turnover Intention
}

\author{
Debitri Primasheila ${ }^{a}$ \\ Badia Perizade $^{b}$ \\ Agustina Hanafi ${ }^{\mathrm{c}}$ \\ Marlina Widiyanti ${ }^{\mathrm{d}}$
}

Article history:

Submitted: 18 October 2021

Revised: 09 November 2021

Accepted: 27 December 2021

\section{Keywords:}

hospital;

job satisfaction;

nursing staff;

organizational commitment;

turnover intention;

\begin{abstract}
This study aimed to find out partially and simultaneously the influences of job satisfaction and organizational commitment on turnover intention of nursing staff at Bunda General Hospital Palembang. This study used qualitative data through questionnaire statements quantified using a Likert scale of 1-5 points to measure the attitudes, opinions, and perceptions. The total population was 144 people of which 20 of them were used in the survey before starting this study. Therefore, the number of samples was 124 people using the population sampling technique. The data were collected by using a questionnaire that had been tested for its validity and reliability with the result that it was reliable and usable. Multiple Regression Analysis Technique was used to analyze the collected data. The results of the study showed that partially the job satisfaction and organizational commitment had a significant influence on turnover intention; and simultaneously, had a negative and significant effect on turnover intention. The findings are expected to be used to improve the performance of nursing staff by providing authority according to task performance, recognition as appreciation for success in completing work well, and increasing organizational commitment to reduce the intention to quit or leave the company.
\end{abstract}

International research journal of management, IT and social sciences (C) 2022. This is an open access article under the CC BY-NC-ND license (https://creativecommons.org/licenses/by-nc-nd/4.0/).

Corresponding author:

Debitri Primasheila,

Master of Management, Sriwijaya University, Palembang, Indonesia.

Email address: debitri77@gmail.com

Master of Management, Sriwijaya University, Palembang, Indonesia

Lecturer of Magister Management, Economic Faculty, Sriwijaya University, Palembang, Indonesia

Lecturer of Magister Management, Economic Faculty, Sriwijaya University, Palembang, Indonesia

Lecturer of Magister Management, Economic Faculty, Sriwijaya University, Palembang, Indonesia 


\section{Introduction}

Hospitals generally function to provide optimal health services for the community. In addition, the hospitals must also have quality resources to support these services. With quality resources, they can produce maximum output in the form of products or services to improve health services.

The tight competition in the development of services in hospitals encourages hospital management to develop their resources so that the desired health services can be achieved properly. Rasche et al. (2017), stated: "Hospitals evolve into economic entities facing severe competition alongside multiple dimensions". In other words, the hospitals are increasingly developing into economic entities that face stiff competition with various dimensions.

According to Mobley et al. (1978), a turnover intention is a form of employee behavior based on the employee's own decision to leave his/her job. According to Robbin (1996), there are two categories of why employees leave their jobs as follows, (1) Voluntary Turnover occurs when the employee's decision to leave the organization voluntarily is due to other professional reasons to terminate the employment relationship with the company, and (2) Involuntary Turnover occurs if the employer's decision to terminate the employee's employment relationship is uncontrollable for the employee undergoing it.

In hospital service companies, nursing staff (nurses and midwives) are one of the determining factors in creating satisfaction for patients because they usually relate to patients from the time of examination to the time they will be hospitalized. According to Rogers et al. (2004), there is a tendency that hospital nursing staff to work longer hours with less rest time and often less time to recover between shifts. Scheduled shifts may be eight, twelve, or even sixteen hours and may not follow the traditional pattern of night and night shifts. While twelve-hour shifts usually start at 7 p.m. and end at 7 a.m., some shifts start at 3 a.m. and end at 3 p.m.

Employee turnover issues which are increasingly high in some working areas may directly affect the human resource procedure of recruiting, selecting, training, and maintaining the workforce. In addition, in case a lot of the number of nursing staff quit the organization, workload, and overtime for existing nursing staff get highly increased, and consequently may reduce their productivity level resulting from low confidence, enthusiasm, and discipline of the employees. For that reason, high productivity and performance can be obtained by considering that it is very essential for a hospital to get support and contribution from their nursing staff (Lapane \& Hughes, 2007). There has been a variety of research and study conducted on turnover issues. For example, job satisfaction can assist to raise employee commitment and motivation. Kristanto et al. (2014), and Saeed et al. (2014), carried out a study on the turnover intention that showed that job satisfaction had a negative and significant effect on turnover intention. Dissatisfied nursing staff would eventually leave the hospitals they work in and at the same time, the hospitals lose the knowledge that they have contributed. In other words, if the hospitals decide to hire new nursing staff to fill those who quit but their dissatisfaction does not comply with them either, this matter might influence the hospital's daily operation. To this end, the turnover will recur again.

Keeping employees in the company is one of the important roles of human resource management in a company. Employees who feel that the company can no longer guarantee their welfare will intend to resign from the company and choose to move to a company that is considered more attractive to them. When they already have the desire to leave, they will feel indifferent to the company, do not care about the activities of the organization, and tend to be closed to the organization. This phenomenon is rife not only in the country but also occurs in several countries, especially in the Asia Pacific region. This employee turnover is caused by the attitude and intention of employees to move or quit their workplace which is called turnover intention (Jacobs \& Roodt, 2007).

Bunda General Hospital (RSUB) Palembang is one of the private hospitals that can be classified as a service provider organization that also relies on the quality of services provided to the community. Speed of service, friendliness, the effectiveness of action, and comfort for patients and visitors will be the key to success in managing a hospital. However, often the performance of hospital management that is already so good will be disrupted by various behaviors of nursing staff that are difficult to prevent. One of these behaviors is the decision of nursing staff to leave the company (turnover). Based on the data from 2016 to 2020, the average percentage of employee turnover at RSU Bunda Palembang was 11.13\% (HRD RSU Bunda Palembang, 2020). According to Gillies (1994), the normal turnover percentage ranges from $5-10 \%$ per year, above $10 \%$ the turnover belongs to a high category.

The presurvey on job satisfaction and organizational commitment was carried out at Bunda General Hospital Palembang to find out the nursing staff's (20 nurses and midwives) perceptions on the two variables (Burhanudin \& Tambun, 2021). The pre-survey focused on the dimensions of the job itself, responsibility, and promotion. The result showed that each employee had a lack of job satisfaction, particularly on the dimension of responsibility in which 75\% of respondents chose Disagree. Presumably, there occurred a feeling of dissatisfaction among the nursing staff. 
Meanwhile, the result of the pre-survey of organizational commitment conducted on 20 respondents of nurses and midwives at RSU Bunda Palembang showed that the three indicators related to organizational commitment, namely Affective, Normative, and Sustainable Commitments, on average agreed by the respondents by $38.33 \%$ which belonged to the medium criteria. In other words, the nursing staff at Bunda Palembang General Hospital might lack a sense of organizational commitment and this phenomenon is an interesting problem to be investigated further.

Robbins et al. (2017), states that "the Organizational Commitment is a state in which an employee takes side to a certain organization and has the goal and intention to hold out his membership at the organization". Organizational commitment is a condition in which an employee sided with a particular organization and has the goals and intentions to maintain membership in the organization (Astiti \& Surya, 2020). In other words, commitment is a form of dedication or obligation that binds to other people, certain things, or certain actions. Commitment itself can be done voluntarily or without coercion. Organizational commitment can be distinguished from job satisfaction (Raziq \& Maulabakhsh, 2015; Sy et al., 2006; Lu et al., 2002). Commitment refers to an individual's emotional response to the whole organization, while satisfaction refers to an emotional response to a specific aspect of the job. The relationship between job satisfaction and intention to leave the workplace only explains a small part of the variance, so it is clear that the employee turnover intention process model must use other variables outside of job satisfaction as the only explanatory variable (Arshadi \& Damiri, 2013; Schwepker Jr, 2001). Turnover intention includes the construct of organizational commitment as a concept that also explains the process as a form of behavior. Organizational commitment can be distinguished from job satisfaction (Chen, 2006; Tnay et al., 2013; Devece et al., 2016). Commitment refers to an individual's emotional (affective) response to the whole organization, while satisfaction refers to an emotional response to a specific aspect of the worker.

\section{Materials and Methods}

In this study, there are approximately three (3) research objectives and hypotheses used as a guideline for the researcher to work on. Below are the specific objectives used as a reference in this study. The specific objectives aimed to find out: 1) partially, the effect of job satisfaction on turnover intention; 2) partially, the effect of organizational commitment on Turnover Intention; and 3) simultaneously the effect of job satisfaction and organizational commitment on Turnover Intention. The conceptual framework was developed based on the effects of independent variables of Job Satisfaction $\left(\mathrm{X}_{1}\right)$ and Organizational Commitment $\left(\mathrm{X}_{2}\right)$ on the dependent variable $(\mathrm{Y})$ Turnover Intention:

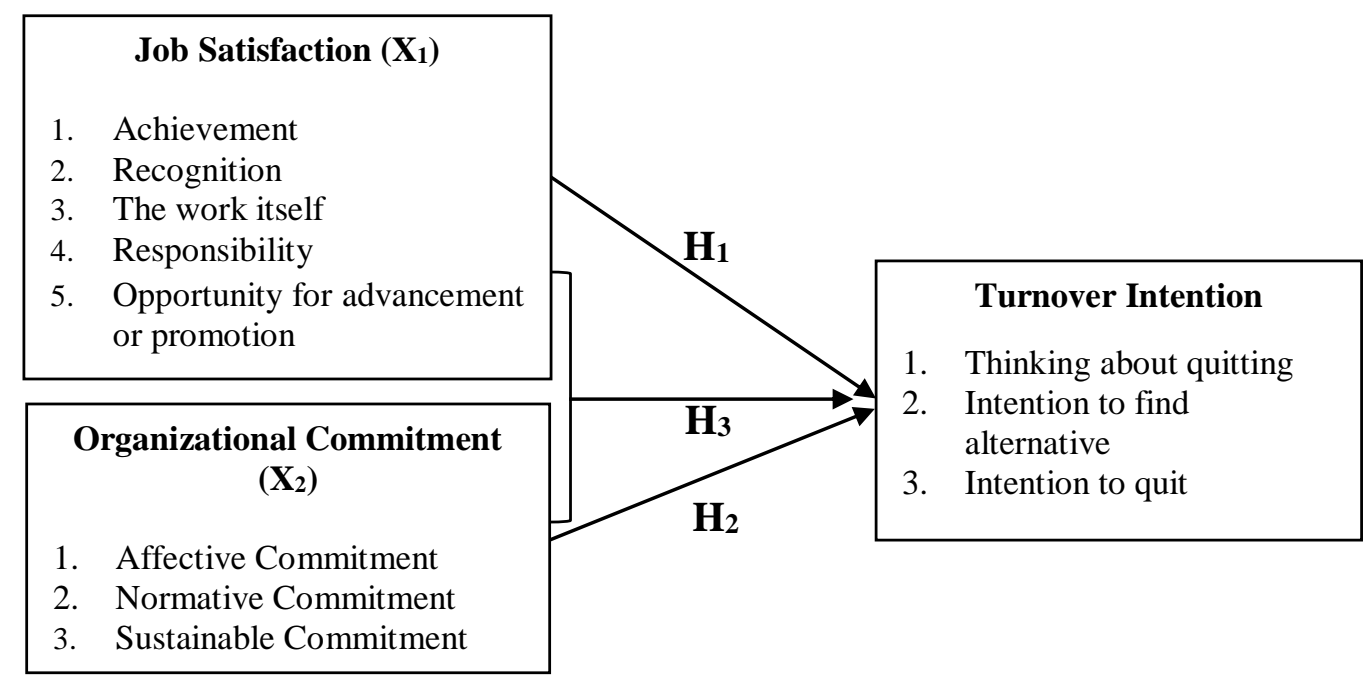

Figure 1. Conceptual framework of the study

\section{Research hypotheses}

The research hypotheses in this study were specific statements of prediction that the researchers expected. Therefore, the researchers used alternate hypotheses to identify if there is a significant effect between the independent variables

Primasheila, D., Perizade, B., Hanafi, A., \& Widiyanti, M. (2022). The influences of job satisfaction and organizational commitment on turnover intention. International Research Journal of Management, IT and Social Sciences, 9(1), 119-130. https://doi.org/10.21744/irjmis.v9n1.2014 
with the dependent variable mentioned earlier. The hypothetical model in this study is based on the theoretical studies made for each problem formulation. The following hypotheses are formulated:

1. $\mathrm{H}_{1}=$ Job Satisfaction has a positive and significant effect on Turnover Intention.

2. $\mathrm{Ho}_{1}=$ Job Satisfaction does not have a positive and significant effect on Turnover Intention.

3. $\mathrm{H}_{2}=$ Organizational Commitment has a positive and significant effect on Turnover Intention.

4. $\mathrm{Ho}_{2}=$ Organizational Commitment has no positive and significant effect on Turnover Intention.

5. $\mathrm{H}_{3}=$ Job Satisfaction and Organizational Commitment have a positive and significant effect on Turnover Intention.

6. $\mathrm{Ho}_{3}=$ Job Satisfaction and Organizational Commitment simultaneously do not effect on Turnover Intention.

In this research, a survey questionnaire was designed according to the objective of the study, and it was used to gather accurate and fewer biased data. The questionnaire consisted of the demographic characteristics of the respondents in the first section followed by 16 statements of job satisfaction, 6 statements of organizational commitment, and 10 statements of turnover intention. These statements were measured using a 5 level Likert scale developed by Likert (Likert, 1932).

The population was 144 respondents of the nursing staff of the RSU Bunda Palembang. The sampling technique used population sampling: all population was taken samples. Twenty of whom were taken samples used in the preliminary survey. Thus, 124 questionnaires were distributed among the nursing staff and the results were analyzed using descriptive and inferential statistics by utilizing the Statistical Package for Social Science (SPSS) version 16.0.

As mentioned earlier, descriptive statistics were used to analyze the respondents' demographic data such as gender, age, educational level, and years of service working in the organization. The data was presented via frequency and percentage. On the other hand, inferential statistics were used to find out the effects of independent variables on the dependent variable. The hypotheses were analyzed using Pearson's Correlation Coefficient, and the signs of the correlation coefficient indicate the strength of the relationship or the degree of association between the two variables. The independent variables for this study include job satisfaction and organizational commitment. On the contrary, the dependent variable was the nursing staff's turnover intention (Revilla-Camacho et al., 2015).

The validity test was carried out by comparing the Pearson Product Moment correlation value found in the data processing results with the help of the SPSS program with the value of $r$ is the Pearson Product Moment table. The critical value of correlation (r-table) with as many as 30 respondents at a significance of 5\% is 3.61 in the PPM $\mathrm{r}_{\text {table }}$. If the $r_{\text {count }}$ is greater than $r_{\text {table }}(0.361)$, the item is valid; If $r_{\text {count }}$ is less than $r_{\text {table }}(0.361)$, the item is invalid.

The results of the validity test of the instrument variables, respectively for the variables Job Satisfaction $\left(\mathrm{X}_{1}\right)$, Organizational Commitment $\left(\mathrm{X}_{2}\right)$, and Turnover Intention $(\mathrm{Y})$ had $\mathrm{r}_{\text {count }}$ greater than $\mathrm{r}_{\text {table }}$. Therefore, all items of the statements in the variables of (X1), (X2), and (Y) were valid and could be used as research instruments in this study.

The results of the instrument reliability test of the research variable showed that the Cronbach Alpha values of the three s of Job Satisfaction $\left(\mathrm{X}_{1}\right)$, Organizational Commitment $\left(\mathrm{X}_{2}\right)$, and Turnover Intention $(\mathrm{Y})$ were $0.970,0.971$, and 972 respectively which were greater than 0.60 . Consequently, all variables in this study could be relied on and used.

Table 1

Results of reliability test

\begin{tabular}{lccccc}
\hline Variable & $\begin{array}{c}\text { Cronbach's } \\
\text { Alpha }\end{array}$ & $\begin{array}{c}\text { Cutt } \\
\text { Off }\end{array}$ & $\begin{array}{c}\text { N of } \\
\text { Case }\end{array}$ & $\begin{array}{c}\text { N of } \\
\text { Item }\end{array}$ & \multirow{2}{*}{ Description } \\
\hline Job satisfaction (X1) & 0,970 & $>0,60$ & 30 & 16 & Reliable \\
Organizational Commitment (X2) & 0,971 & $>0,60$ & 30 & 6 & Reliable \\
Turnover Intention (Y) & 0,972 & $>0,60$ & 30 & 10 & Reliable \\
\hline
\end{tabular}

Source: Processed Questionnaire Data, 2021 


\section{Results and Discussions}

\section{Demographic characteristics}

Table 1 shows the range of age and gender of the respondents. There were 16 males (about 13\%) fewer than females (87\%). Meanwhile, the majority of the age of the nursing staff ranged between 25 - 34 years old (92 respondents).

Table 2

The range of age and gender

\begin{tabular}{rrccc}
\hline No. & Range of Age & $\begin{array}{c}\text { Number of Male } \\
\text { Respondents }\end{array}$ & $\begin{array}{c}\text { Number of Female } \\
\text { Respondents }\end{array}$ & Total \\
\hline 1 & $20-24$ years old & 2 & 4 & 6 \\
2 & $25-29$ years old & 11 & 40 & 51 \\
3 & $30-34$ years old & 2 & 39 & 41 \\
4 & $35-39$ years old & 1 & 11 & 12 \\
5 & $40-44$ years old & - & 5 & 5 \\
6 & $45-49$ years old & - & 5 & 5 \\
7 & $50-54$ years old & - & 2 & 2 \\
8 & $55-59$ years old & - & - & - \\
9 & $60-64$ years old & - & 2 & 124 \\
& Total & 16 & 108 & \\
\hline
\end{tabular}

Source: Processed Questionnaire Data, 2021

As for the education qualifications and tenure of service, Table 2 indicates that there were 83 respondents (67\%) who graduated from Diploma 3 Nursing and Midwifery Education Program, and 41 respondents (33\%) graduated from the Nursing Profession study program. The tenure of them was categorized into three groups of years of service, namely less than 2 years of service, 2 to 5 years of service, and more than 5 years of service.

Table 3

Education qualifications and tenure of service

\begin{tabular}{clcccc}
\hline No & Education Qualification & $<2$ Years & $2-5$ Years & $>$ 5 Years & Total \\
\hline 1 & D3 Nursing & 10 & 35 & 4 & 49 \\
2 & D3 Midwifery & 5 & 14 & 15 & 34 \\
3 & Undergraduate Professional Nurse & 25 & 10 & 6 & 41 \\
& Total & 40 & 59 & 25 & 124 \\
\hline
\end{tabular}

Source: Processed Questionnaire Data, 2021

\section{Classical assumption test results}

Normality test results

The normality test is the normality of the data distribution. in parametric statistical analysis, it is used for the assumption that the data is normally distributed (Suharyadi \& Purwanto, 2004). Meanwhile, according to Sulhan (2009), the normality test is intended to determine whether the residuals of the regression model studied are normally distributed or not. The test normality used the Kolmogorov-Smirnov test $>0.05$.

According to Latan \& Temalagi (2013), the normality can be detected by looking at the spread of point data on the diagonal axis of the graph. If the data spread around the diagonal line and follows the direction of the diagonal line, then the regression model fulfills the assumption of normality. On the other hand, if the data spreads far from the diagonal line and or does not follow the direction of the diagonal line, then the regression model does not meet the assumption of normality. Figure 1 shows that the data were normally distributed since they spread around the diagonal line and followed the direction of the diagonal line, the regression model fulfilled the assumption of normality.

Primasheila, D., Perizade, B., Hanafi, A., \& Widiyanti, M. (2022). The influences of job satisfaction and organizational commitment on turnover intention. International Research Journal of Management, IT and Social Sciences, 9(1), 119-130. https://doi.org/10.21744/irjmis.v9n1.2014 


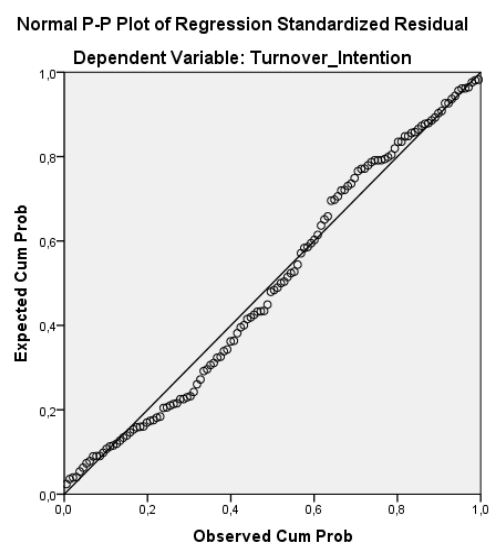

Figure 1. Normality test results with Scatter Plot

\section{Multicollinearity test results}

A multicollinearity test was conducted to test whether the regression model found a correlation between the independent variables. Table 4 shows that there was no multicollinearity between the independent variables because it shows a VIF value of less than 10 . Thus, in this model, there was no multicollinearity problem.

Table 4

Multicollinearity test results

\begin{tabular}{lccc}
\hline Variables & VIF & Cutt Off & Remarks \\
\hline Job Satisfaction (X1) & 1,001 & $>10$ & No Multicollinearity \\
Organizational Commitment (X2) & 1,001 & $>10$ & No Multicollinearity \\
\hline
\end{tabular}

Source: Processed Questionnaire Data, 2021

\section{Heteroscedasticity test results}

Heteroscedasticity was tested using the Spearman rank correlation coefficient test, which correlated the absolute residuals of the regression results with all independent variables. Figure 3 shows that the residual data spread well above and below point 0 in the regression model and did not form a certain pattern. Since a good model is obtained if there is no certain pattern on the graph, such as gathering in the middle, narrowing then widening, and vice versa. Consequently, there was no symptom of heteroscedasticity in the regression model.

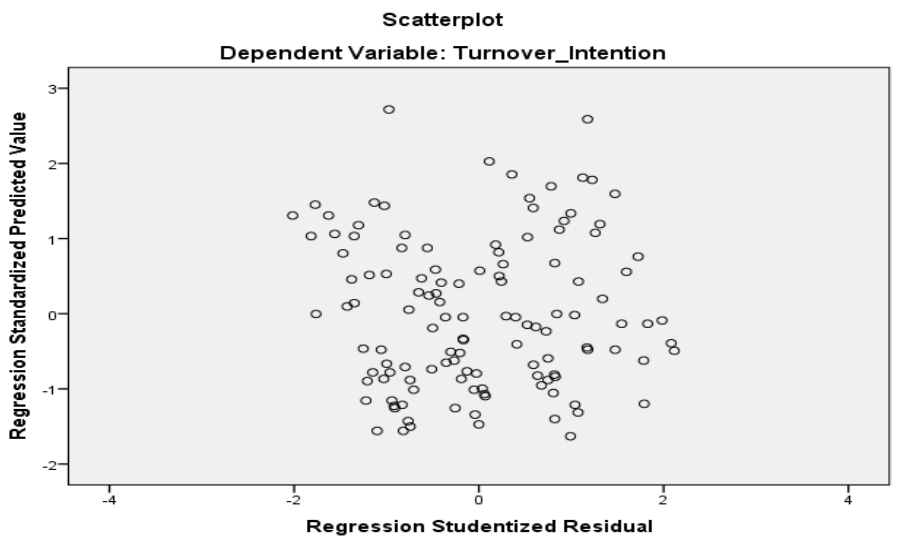

Figure 2. Normality Test Results with Scatter Plot

Source: Processed Questionnaire Data, 2021 
Multiple linear regression analysis results

Multiple linear regression analysis was used to find out the direct relationship that occurred between the independent variables, namely Job Satisfaction (X1) and Organizational Commitment (X2), to the dependent variable, namely Turnover Intention (Y). Table 5 shows the results of multiple linear regression calculations.

Table 5

Results of multiple linear regression analysis test

\begin{tabular}{llccc}
\hline & & \multicolumn{3}{c}{ Coefficients $^{\mathrm{a}}$} \\
\hline \multirow{2}{*}{ Model } & Unstandardized Coefficients & Standardized Coefficients \\
\cline { 3 - 5 } & (Constant) & B & SD & Beta \\
& Job Satisfaction & 43,538 & 4,317 & \\
& Organizational Commitment &,- 146 &, 057 &,- 223 \\
& $-5,340$ &, 151 &,- 95 \\
\hline
\end{tabular}

Source: Processed Questionnaire Data, 2021

$$
\mathrm{KK}=43,538+(-, 146) \mathrm{b}_{1} \cdot \mathrm{X}_{1}-0,100 \mathrm{~b}_{2} \cdot \mathrm{X}_{2}
$$

From Table 5, three conclusions are drawn as follows:

(1) The constant value of 43,538 indicates that if there are no Job Satisfaction and Organizational Commitment variables then Turnover Intention is 43,538.

(2) The regression coefficient value of the Job Satisfaction variable is -0.146 , indicating that if the Job Satisfaction variable is added by 1 unit, Turnover Intention will decrease by -0.146 .

(3) The regression coefficient value for the Organizational Commitment variable is -0.340 indicating that if the Organizational Commitment variable is added by 1 unit, the Turnover Intention will decrease by -0.340 .

Results of Correlation Coefficient ( $r$ ) and Coefficient of Determination (R2)

The value of the correlation coefficient $(\mathrm{r})$ between the independent variable and the dependent variable was 0.817 or $81.7 \%$ shown in Table 6 as follows:

Table 6

Test Results of Correlation Coefficient (r) and Coefficient of Determination (R2)

\begin{tabular}{ccccc}
\hline & \multicolumn{3}{c}{ Model Summary $^{\mathrm{b}}$} \\
\hline Model & $\mathrm{R}$ & R Square & Adjusted R Square & Std. Error of the Estimate \\
\hline 1 & $0.817^{\mathrm{a}}$ & 0.668 & 0.659 & 3,53556
\end{tabular}

Source: Processed Questionnaire Data, 2021

This showed that the correlation or relationship between the independent variable and the dependent variable was very strong (in the range of $0.80-1.00$ ) which can be seen in Table 7 . The close relationship and the magnitude of the influence between the independent variable and the dependent variable are given in Table 7 as follows:

Table 7

Guidelines of correlation coefficient interpretation

\begin{tabular}{cc}
\hline Interval Coefficient & Relationship Level \\
\hline $0.00-0.199$ & Very Low \\
$0.20-0.399$ & Low \\
$0.40-0.599$ & Medium \\
$0.60-0.799$ & Strong \\
$0.80-1.000$ & Very Strong \\
\hline
\end{tabular}

Source: Sugiyono, 2008

Primasheila, D., Perizade, B., Hanafi, A., \& Widiyanti, M. (2022). The influences of job satisfaction and organizational commitment on turnover intention. International Research Journal of Management, IT and Social Sciences, 9(1), 119-130. https://doi.org/10.21744/irjmis.v9n1.2014 
The coefficient of determination $\left(\mathrm{R}^{2}\right)$ of 0.668 indicated that the independent variables, namely Job Satisfaction (X1) and Organizational Commitment (X2) explained the dependent variable, namely Turnover Intention (Y) of 66.8\%, while the remaining $33.2 \%$ was explained by other factors excluded in this study such as motivation, compensation, skills, training, facilities and infrastructure, career development and work environment (Armstrong \& Baron, 1998).

\section{Hypothesis test results}

Partial test results ( $t$-Test)

The t-test was used to test the significance of the relationship between the independent and dependent variables, whether the independent variables affected the dependent variable partially. For this test, the obtained coefficient values were real or not between $t_{\text {count }}$ at the $5 \%$ confidence level or $=0.05$. The results of the $t$-test can be seen in Table 8 as follows:

Tabel 8

Partial test results (t-Test)

\begin{tabular}{llccc}
\hline \multicolumn{1}{c}{ Coefficients ${ }^{\mathrm{a}}$} \\
\hline \multirow{2}{*}{ Model } & $\begin{array}{c}\text { Standardized } \\
\text { Coefficients Beta }\end{array}$ & $\mathrm{t}$ & Sig. \\
\hline 1 & (Constant) &,- 223 & 10,086 &, 000 \\
& Job Satisfaction &,- 195 & $-2,565$ &, 012 \\
& Organizational Commitment & $-2,253$ &, 026 \\
\hline
\end{tabular}

Source: Processed Questionnaire Data, 2021

Table 8 reveals that $(1)$ the Job Satisfaction Variable $\left(\mathrm{X}_{1}\right)$ has a significant value of 0.012 which is smaller than 0.05. This means that the Job Satisfaction variable $\left(\mathrm{X}_{1}\right)$ has a significant influence on Turnover Intention $(\mathrm{Y})$. These results indicate that the first hypothesis on the Job Satisfaction variable has a negative and significant effect on the Turnover Intention of Nursing Staff at Bunda Hospital Palembang, and (2) the Organizational Commitment Variable $\left(\mathrm{X}_{2}\right)$ has a significant value of 0.026 which is smaller than 0.05 . This means that the variable Organizational Commitment $\left(\mathrm{X}_{2}\right)$ has a significant effect on Turnover Intention (Y). These results indicate that the second hypothesis on the variable organizational commitment has a negative and significant effect on the Turnover Intention of Nursing Staff at Bunda Hospital Palembang.

\section{Feasibility test results (Test F)}

The results of the $\mathrm{F}$ test were used to show whether all the independent variables included in the model together influenced the dependent variable. $F_{\text {table }}$ was obtained from the significant level (0.05) with df $1=\mathrm{k}-1$ (number of variables $=3-1=2)$ and $\mathrm{df} 2=(\mathrm{n}-\mathrm{k}-1)(124-2-1=121)$ then the value obtained from the $\mathrm{F}_{\text {table }}$ was 3.08 . From the calculation, the $F_{\text {count }}$ value was 6.007. Due to the value of $F_{\text {count }}>F_{\text {table }}(4.089>3.08)$, while the significance level was $0.003<0.05$, then Ho was rejected and $\mathrm{H}$ was accepted, meaning that job satisfaction (X1) and organizational commitment (X2) variables significantly affected turnover intention (Y). Thus, these results answer the research objective that job satisfaction affects turnover intention.

Table 9

F-test results

\begin{tabular}{llrrccc}
\hline & Model & Sum of Squares & df & Mean Square & F & Sig. \\
\hline 1 & Regression & 1401.460 & 2 & 700.730 & 6.007 & $.003^{\mathrm{b}}$ \\
Residual & 14114.411 & 121 & 116.648 & & \\
& Total & 15515.871 & 123 & & & \\
\hline
\end{tabular}

a. Dependent Variable: Turnover Intention

b. Predictors: (Constant), Job Satisfaction, Organizational Commitment

Source: Processed Questionnaire Data, 2021 
Guidelines of frequency measurement category

Following the measurement guidelines according to Azwar (2012), the frequency of the items chosen by the respondents was categorized into three, Low, Medium, and High of each variable as follows:

Table 10

Guidelines of frequency measurement category

\begin{tabular}{llll}
\hline Variables & Low & Medium & High \\
\hline Job Satisfaction & $\mathrm{X}<40$ & $40 \leq \mathrm{X}<56$ & $56 \leq \mathrm{X}$ \\
Organizational Commitment & $\mathrm{X}<14$ & $14 \leq \mathrm{X}<22$ & $22 \leq \mathrm{X}$ \\
Turnover Intention & $\mathrm{X}<23,33$ & $23,33 \leq \mathrm{X}<36,67$ & $36,67 \leq \mathrm{X}$ \\
\hline
\end{tabular}

\section{The effect of job satisfaction on turnover intention}

The results of the partial test (t-test) showed that the Job Satisfaction variable $\left(\mathrm{X}_{1}\right)$ da a significant value of 0.012 which was smaller than 0.05 . This means that the job satisfaction variable had a significant influence on the turnover intention variable (Y) of health workers at Bunda Hospital Palembang. In other words, the higher the job satisfaction of health workers at Bunda Hospital in Palembang, their turnover intention will decrease. This is in line with the theory of job satisfaction factors (Syptak et al., 1999; Weir, 1976) that strong determinants of job satisfaction are achievement, recognition, work itself, responsibility, and opportunities for advancement or promotion. This result is supported by the frequency of respondents' answers related to the job satisfaction variable; the average total value is 57, meaning that based on the category criteria for calculating the frequency of the Job Satisfaction variable, it is in the high category. More interestingly, the total average of all respondents' answers to each statement (16 statement items) on the job satisfaction variable was 3.405 interpreted as a "neutral" category. In other words, there was the potential for health workers at Bunda Hospital to be satisfied and dissatisfied at the same time.

The results of previous relevant studies were among others conducted by Anggraeni \& Perdhana (2016), Ibrar (2015), Sakul (2018), De Simone et al. (2018), Reukauf (2018), Susilo \& Satrya (2019), and Setiyanto \& Hidayati (2017) regarding job satisfaction on turnover intention also showed a strong influence of job satisfaction on turnover intention.

\section{The effect of organizational commitment on turnover intention}

Partially, based on the results of the t-test, the variable Organizational Commitment $\left(\mathrm{X}_{2}\right)$ has a significant value of 0.026 which is smaller than 0.05 indicating that this variable had a significant effect on turnover intention. Thus, the result proves that the second hypothesis has a negative and significant effect on the turnover intention variable for health workers at Bunda Hospital Palembang. That is, the higher the level of organizational commitment of health workers, the lower their turnover intention.

The results of this study are supported by the results of previous relevant research conducted by Pelamonia (2019), that leadership, among others, affects employee performance. The same thing is also shown from the results of Kuntardina's research (Kuntardina, 2017), which states that organizational justice and supervisor-employee relationships affect nurses' intentions to change their jobs.

Based on the theory according to Robbins et al. (2017), that organizational commitment shows the state of an employee in favor of a particular organization and its goals and desires to maintain membership in the organization. It can be said that high involvement means taking sides with an employee's particular job. Meanwhile, high organizational commitment means siding with the organization that recruited the employee. The organizational commitment variable asked for 6 (six) statement items. The result was also supported by the category criteria for calculating the average frequency of the Organizational Commitment variable with a value of 23 , 467 or in the high category.

The results of the partial test (T-test) indicate that the variable Organizational Commitment had a positive and significant effect on the Turnover Intention of Nursing Personnel at Bunda Hospital Palembang. The organizational commitment identified as how far health workers identify themselves with the organization and their involvement in certain organizations is very important in reducing the turnover intention of health workers at Bunda Palembang Hospital. The positive commitment of health workers will reduce their intention to leave the company. According to

Primasheila, D., Perizade, B., Hanafi, A., \& Widiyanti, M. (2022). The influences of job satisfaction and organizational commitment on turnover intention. International Research Journal of Management, IT and Social Sciences, 9(1), 119-130. https://doi.org/10.21744/irjmis.v9n1.2014 
Robbins and Judge (Robbins et al., 2017), organizational commitment is a condition in which an employee sided with a particular organization and its goals and desires to maintain membership in the organization. For that reason, job involvement means taking sides with an individual's particular job, while organizational commitment means taking sides with the organization that recruited the individual.

The simultaneous effect of job satisfaction and organizational commitment on turnover intention

This study showed that there was a significant effect between job satisfaction and organizational commitment on the turnover intention of nursing staff at Bunda Hospital Palembang. The results of linear regression indicated that the correlation between the independent and dependent variables is very strong. These results are supported by some of the relevant previous studies conducted by Ibrar (2015), Sakul (2018), Putra et al. (2017), and Susilo \& Satrya (2019), that job satisfaction and organizational commitment partially and simultaneously affect turnover intention.

\section{Conclusion}

Based on the research objectives and hypotheses that have been determined in the previous chapter, the results of the data analyses showed that job satisfaction had a positive significant effect on the turnover intention of health workers at Bunda Hospital Palembang, the organizational commitment had a significant negative effect on the turnover intention of health workers at Bunda Hospital Palembang, and there was a significant effect between job satisfaction and organizational commitment on the turnover intention of nursing staff at Bunda Hospital Palembang.

\section{Conflict of interest statement}

The authors declared that they have no competing interests.

Statement of authorship

The authors have a responsibility for the conception and design of the study. The authors have approved the final article.

\section{Acknowledgments}

The author expresses his deep gratitude to the academic parties who have provided support in the form of feedback. 


\section{References}

Anggraeni, M., \& Perdhana, M. S. (2016). Kepuasan Kerja, Komitmen Organisasi, Dan Turnover Intention Di PT. Hillconjaya Sakti, Cakung, Jakarta Timur (Doctoral dissertation, Fakultas Ekonomika dan Bisnis).

Armstrong, M., \& Baron, A. (1998). Performance management: the new realities. London: Institute of Personnel and Development.

Arshadi, N., \& Damiri, H. (2013). The relationship of job stress with turnover intention and job performance: Moderating role of OBSE. Procedia-Social and Behavioral Sciences, 84, 706-710. https://doi.org/10.1016/j.sbspro.2013.06.631

Astiti, M. W., \& Surya, I. B. K. (2020). The role of organizational commitments in mediating the effect of work motivation and job satisfaction towards turnover intention on nurses private hospital. International Research Journal of Management, IT and Social Sciences, 8(1), 25-34. https://doi.org/10.21744/irjmis.v8n1.1101

Azwar, S. (2012). Penyusun Skala Psikologi Edisi 2 Cetakan 2.

Burhanudin, B., \& Tambun, R. (2021). Effect of direct and indirect financial compensation on job satisfaction. International Research Journal of Management, IT and Social Sciences, 8(2), 163-174. https://doi.org/10.21744/irjmis.v8n2.1376

Chen, C. F. (2006). Job satisfaction, organizational commitment, and flight attendants' turnover intentions: A note. Journal of Air Transport Management, 12(5), 274-276. https://doi.org/10.1016/j.jairtraman.2006.05.001

De Simone, S., Planta, A., \& Cicotto, G. (2018). The role of job satisfaction, work engagement, self-efficacy and agentic capacities on nurses' turnover intention and patient satisfaction. Applied Nursing Research, 39, 130-140. https://doi.org/10.1016/j.apnr.2017.11.004

Devece, C., Palacios-Marqués, D., \& Alguacil, M. P. (2016). Organizational commitment and its effects on organizational citizenship behavior in a high-unemployment environment. Journal of Business Research, 69(5), 1857-1861. https://doi.org/10.1016/j.jbusres.2015.10.069

Gillies, D. A. (1994). Nursing management: A system approach.

Ibrar, M. (2015). The influences of employee job satisfaction an organizational commitment on turnover intention. Arabian Journal of Bussiness and Management Review, 6(1).

Jacobs, E., \& Roodt, G. (2007). The development of a knowledge sharing construct to predict turnover intentions. In Aslib Proceedings. Emerald Group Publishing Limited.

Kristanto, S., Rahyuda, I. K., \& Riana, I. G. (2014). Pengaruh keadilan organisasional terhadap kepuasan kerja dan dampaknya terhadap komitmen, dan intensi keluar di pt indonesia power ubp bali. E-Jurnal Ekonomi dan Bisnis Universitas Udayana, 3(6), 308-329.

Kuntardina, A. (2017). Nurses and Staff Turnover Intentions in Private Hospitals'. Advances in Intelligent Systems Research, 131.

Lapane, K. L., \& Hughes, C. M. (2007). Considering the employee point of view: perceptions of job satisfaction and stress among nursing staff in nursing homes. Journal of the American Medical Directors Association, 8(1), 8-13. https://doi.org/10.1016/j.jamda.2006.05.010

Latan, H., \& Temalagi, S. (2013). Analisis multivariate teknik dan aplikasi menggunakan program IBM SPSS 20.0. Bandung: Alfabeta, 146.

Likert, R. (1932). A technique for the measurement of attitudes. Archives of psychology.

Lu, K. Y., Lin, P. L., Wu, C. M., Hsieh, Y. L., \& Chang, Y. Y. (2002). The relationships among turnover intentions, professional commitment, and job satisfaction of hospital nurses. Journal of Professional Nursing, 18(4), 214-219. https://doi.org/10.1053/jpnu.2002.127573

Mobley, W. H., Horner, S. O., \& Hollingsworth, A. T. (1978). An evaluation of precursors of hospital employee turnover. Journal of Applied psychology, 63(4), 408.

Putra, E. D., Cho, S., \& Liu, J. (2017). Extrinsic and intrinsic motivation on work engagement in the hospitality industry: Test of motivation crowding theory. Tourism and Hospitality Research, 17(2), 228-241.

Rasche, C., Margaria, T., \& Floyd, B. D. (2017). Service model innovation in hospitals: Beyond expert organizations. In Service business model innovation in healthcare and hospital management (pp. 1-20). Springer, Cham.

Raziq, A., \& Maulabakhsh, R. (2015). Impact of working environment on job satisfaction. Procedia Economics and Finance, 23, 717-725. https://doi.org/10.1016/S2212-5671(15)00524-9

Reukauf, J. A. (2018). The correlation between job satisfaction and turnover intention in small business (Doctoral dissertation, Walden University).

Primasheila, D., Perizade, B., Hanafi, A., \& Widiyanti, M. (2022). The influences of job satisfaction and organizational commitment on turnover intention. International Research Journal of Management, IT and Social Sciences, 9(1), 119-130. https://doi.org/10.21744/irjmis.v9n1.2014 
Revilla-Camacho, M. Á., Vega-Vázquez, M., \& Cossío-Silva, F. J. (2015). Customer participation and citizenship behavior effects on turnover intention. Journal of business research, 68(7), 1607-1611. https://doi.org/10.1016/j.jbusres.2015.02.004

Robbin, S. (1996). Organizational Behavior, Englewood Cliff. New Jersey.

Robbins, S. P., Judge, T. A., \& Vohra, N. (2017). Organizational Behavior: Emotions and Moods.

Rogers, A. E., Hwang, W. T., Scott, L. D., Aiken, L. H., \& Dinges, D. F. (2004). The working hours of hospital staff nurses and patient safety. Health affairs, 23(4), 202-212.

Saeed, I., Waseem, M., Sikander, S., \& Rizwan, M. (2014). The relationship of turnover intention with job satisfaction, job performance, leader member exchange, emotional intelligence and organizational commitment. International Journal of Learning and Development, 4(2), 242-256.

Sakul, A. (2018). Pengaruh Kepuasan Kerja, Beban Kerja Dan Komitmen Organisasi Terhadap Turnover Intention Perawat RS. Bhayangkara TK. III Manado. Jurnal Riset Bisnis dan Manajemen, 6(2), 175-184.

Schwepker Jr, C. H. (2001). Ethical climate's relationship to job satisfaction, organizational commitment, and turnover intention in the salesforce. Journal of business research, 54(1), 39-52. https://doi.org/10.1016/S01482963(00)00125-9

Setiyanto, A. I., \& Hidayati, S. N. (2017). Pengaruh Kepuasan Kerja dan Komitmen Organisasi terhadap Turnover Intention. Jurnal Akuntansi, Ekonomi Dan Manajemen Bisnis, 5(1), 105-110.

Suharyadi \& Purwanto. (2004). Metodologi Penelitian. Gramedia Pustaka Utama, Jakarta.

Sulhan. (2009). Panduan Praktis SPSS untuk Manajemen (Keuangan, SDM, Pemasaran). Fakultas Ekonomi Universitas Islam Negeri Malang, Malang.

Susilo, J., \& Satrya, I. G. B. H. (2019). Pengaruh Kepuasan Kerja Terhadap Turnover Intention Yang Dimediasi Oleh Komitmen Organisasional Karyawan Kontrak. E-Jurnal Manajemen Universitas Udayana, 8(6), 3700.

Sy, T., Tram, S., \& O'hara, L. A. (2006). Relation of employee and manager emotional intelligence to job satisfaction and performance. Journal of vocational behavior, 68(3), 461-473. https://doi.org/10.1016/j.jvb.2005.10.003

Syptak, J. M., Marsland, D. W., \& Ulmer, D. (1999). Job satisfaction: Putting theory into practice. Family practice management, 6(9), 26.

Tnay, E., Othman, A. E. A., Siong, H. C., \& Lim, S. L. O. (2013). The influences of job satisfaction and organizational commitment on turnover intention. Procedia-Social and Behavioral Sciences, 97, 201-208. https://doi.org/10.1016/j.sbspro.2013.10.223

Weir, M. (Ed.). (1976). Job satisfaction: challenge and response in modern Britain. Fontana Press. 